\title{
GDF3 wt Allele
}

National Cancer Institute

\section{Source}

National Cancer Institute. GDF3 wt Allele. NCI Thesaurus. Code C101650.

Human GDF3 wild-type allele is located in the vicinity of 12 p13.1 and is approximately $6 \mathrm{~kb}$ in length. This allele, which encodes growth/differentiation factor 3 protein, plays a role in cellular differentiation in embryogenesis and during maturation. Mutation of the gene is associated with Klippel-Feil syndrome type 3, microphthalmia isolated with coloboma type 6 and microphthalmia isolated type 7. 